\title{
Floods of July 18-20, 1996, in Northern Illinois
}

By Robert R. Holmes, Jr., and Amanda L. Kupka

U.S. GEOLOGICAL SURVEY

Open-File Report 97-425

Prepared in cooperation with the

ILLINOIS DEPARTMENT OF NATURAL RESOURCES, OFFICE OF WATER RESOURCES

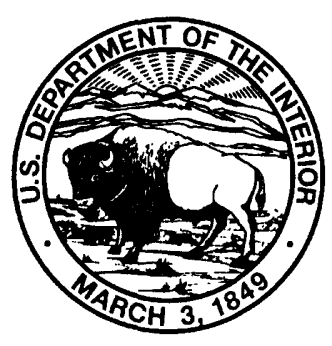




\title{
U.S. DEPARTMENT OF THE INTERIOR BRUCE BABBITT, Secretary
}

\author{
U.S. GEOLOGICAL SURVEY \\ Mark Schaefer, Acting Director
}

The use of firm, trade, and brand names in this report is for identification purposes only and does not constitute endorsement by the U.S. Geological Survey

For additional information write to:

District Chief

U.S. Geological Survey

221 North Broadway Avenue

Urbana, Illinois 61801
Copies of this report can be purchased from:

U.S. Geological Survey

Branch of Information Services

Box 25286

Federal Center

Denver, CO 80225 


\section{CONTENTS}

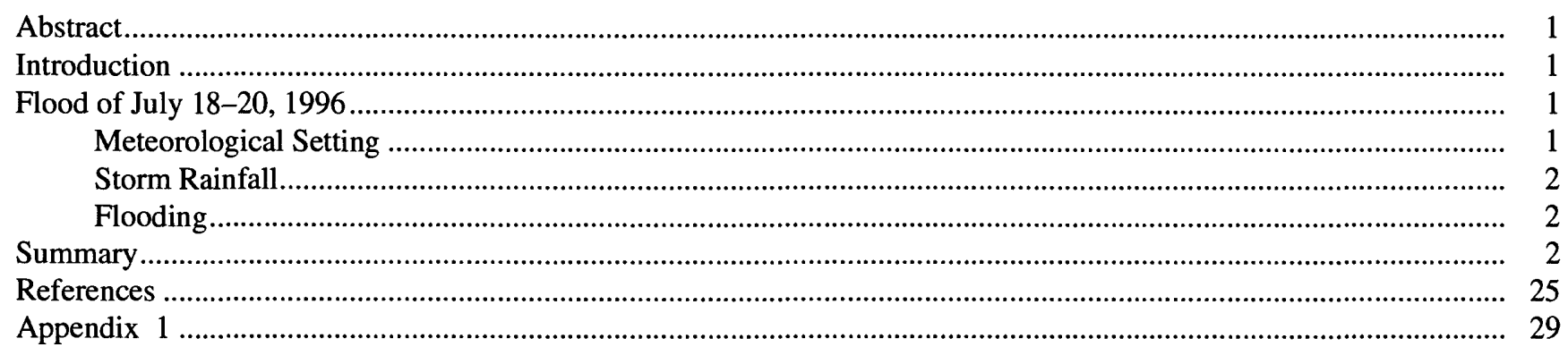

\section{PLATE}

[Plate is in pocket]

1. Rain-gage locations, point-rainfall observations, rainfall isohyets, U.S. Geological Survey streamflow-gaging station locations, and flood-frequency estimates in the northern Illinois flood area

\section{FIGURES}

1. Map showing point-rainfall observations and Illinois State Water Survey rainfall isohyets in the northern Illinois flood area

2. Photographs showing aerial views of flooding in Kane County, Ill

3. Graph showing cumulative rainfall amounts from midnight July 17, 1996, at selected U.S. Geological Survey rain gages in the northern Illinois flood area

4. Map showing U.S. Geological Survey streamflow-gaging stations in the northern Illinois flood area.

5. Graph showing flood-discharge hydrographs for selected U.S. Geological Survey streamflow-gaging stations in the northern Illinois flood area

\section{TABLES}

1. Rainfall data for a 24-hour period at selected rain gages in northern Illinois, July 17-18, 1996

2. Peak-flow data at selected U.S. Geological Survey streamflow-gaging stations in the northern Illinois flood area.

3. High water marks from Illinois Department of Natural Resources crest-stage gages in the northern

Illinois flood area. 


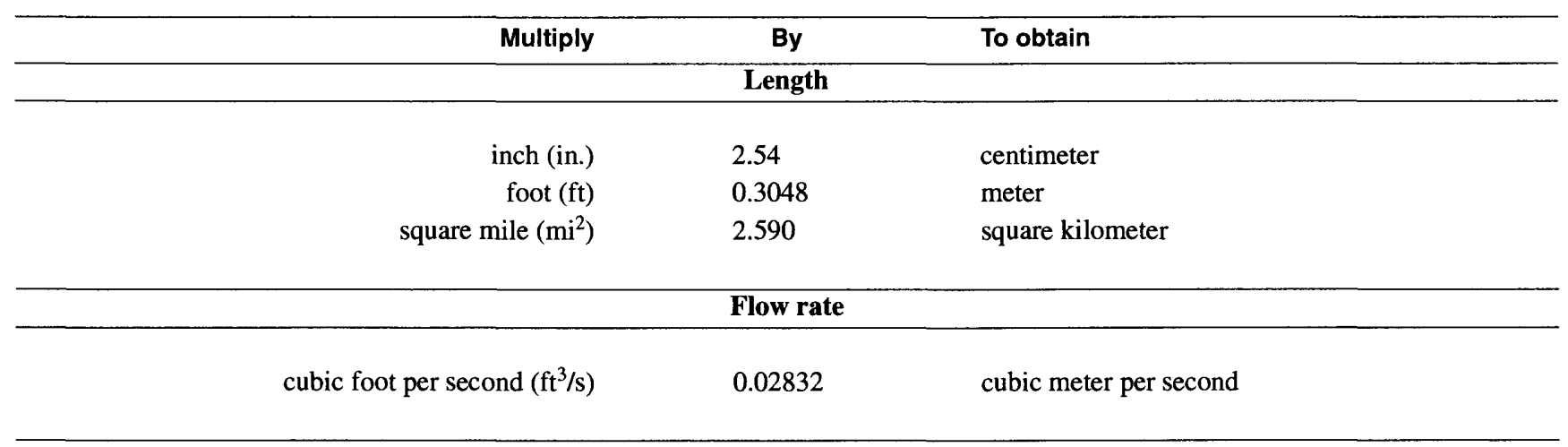

Sea level: In this report, "sea level" refers to the National Geodetic Vertical Datum of 1929 (NGVD of 1929) - a geodetic datum derived from a general adjustment of the first-order level nets of both the United States and Canada, formerly called Sea Level Datum of 1929. 


\title{
Floods of July 18-20, 1996, in Northern Illinois
}

\author{
by Robert R. Holmes, Jr., and Amanda L. Kupka
}

\section{ABSTRACT}

Record flooding occurred on many streams in northern Illinois during July 18-20, 1996. Over 16 inches of rain fell at some locations during and just prior to this period. Peak of record discharges were recorded at 19 U.S. Geological Survey (USGS) streamflow-gaging stations. The USGS, in cooperation with the Illinois Department of Natural Resources, Office of Water Resources (IDNROWR), has compiled the available hydrologic data from the July 1996 flood in northern Illinois, and the data are presented in this report.

\section{INTRODUCTION}

Record rainfall amounts over 16 in. were reported for the 24-hour period ending at 7:00 a.m. on July 18, 1996, in northern Illinois. These amounts resulted from several subsequent thunderstorms tracking along the same west to east stalled low-pressure front. This rainfall produced record flooding in highly urbanized northern Illinois (fig. 1) from July 18 through July 20, 1996. This flooding caused hundreds of millions of dollars worth of damage and two deaths (Chicago Tribune, July 21 and July 26, 1996). Numerous houses were inundated (fig. 2), and roadway infrastructure in the area was damaged as many roads and bridges were washed out. Three dams in the region experienced complete failure, whereas numerous other dams were overtopped experiencing varying degrees of damage. Illinois Governor Jim Edgar declared 15 northern Illinois counties State disaster areas, followed by a Federal disaster declaration of 11 Illinois counties by President Bill Clinton.

Because of the extreme nature of this flood, documenting and archiving the data collected during this flood are valuable for future engineering, environmental, and hydrologic studies. Various Federal and State agencies collected hydrologic data in the flood area. The U.S. Geological Survey (USGS), in cooperation with the Illinois Department of Natural Resources, Office of Water Resources (IDNROWR), has compiled the available data from the July $18-20,1996$, flood in northern Illinois. The purpose of this report is to document and present these data.

\section{FLOOD OF JULY 18-20, 1996}

\section{Meteorological Setting}

Beginning midmorning on July 17, 1996, a slow moving low-pressure system stalled over northern Illinois (fig. 1). Because abundant moisture from the Gulf of Mexico was available in the upper atmosphere, convective heating by the sun caused atmospheric instability over the area. Over the next 24 hours, winds at the 10,000-20,000 feet level running parallel to the front along a west to east track was the mechanism for channeling each developing thunderstorm along the same track, roughly from Rockford to Joliet, Ill. This effect has been referred to as the "train echo." This weather system caused appreciable rainfall along the storm track. Chagnon (1997) gives a more detailed discussion of the meteorological setting for this flood event. 


\section{Storm Rainfall}

Rainfall amounts were heaviest in Du Page, Kane, Kendall, and Will Counties: the National Weather Service (NWS) rain gage in Aurora officially recording $16.91 \mathrm{in}$. This amount is a new State of Illinois record for 24-hour rainfall, surpassing the former record of $16.64 \mathrm{in}$. officially recorded in East St. Louis in southwestern Illinois in 1957. Based on Bulletin 70 (Huff and Angel, 1989), recurrence intervals of greater than 100 years were estimated for long-term NWS rain gages at De Kalb (8.09 in.) and Aurora (16.91 in.). The observations of point rainfall from 117 locations were recorded by NWS, USGS, Illinois State Water Survey (ISWS), and other local agency rain gages in the flood area listed in table 1 . Point-rainfall observations and isohyets of rainfall, modified from Chagnon (1997), are shown in figure 1. The isohyets of rainfall were drawn based on weather radar data and from observations of point rainfall recorded at rain gages. The larger amounts of rain fell along a line from Rockford to Joliet, coinciding with the stalled low-pressure front.

The time distribution of rainfall was nonuniform during the period because rain fell during scattered thunderstorms. The time distribution of rainfall measured at two USGS continuous tipping-bucket rain gages, Du Page County Airport near St. Charles, Ill. (415457088150600, map reference number R87), and Sawmill Creek near Lemont, Ill. (05533400, map reference number R102), are shown in figure 3 . The digital time-series rainfall data (in 5-, 15-, or 60-minute increments) for all USGS and ISWS rain gages in the study area are given in appendix 1 . The rainfall data presented in this report are the recorded values from the rain gage and have had no corrections applied for intense rainfall.

\section{Flooding}

Large amounts of rain fell in some of the most heavily urbanized areas in Illinois. Urbanization tends to worsen flooding during rainstorms because the amount of pervious surfaces to absorb rainfall is decreased. The USGS operates over 65 continuousrecording streamflow-gaging stations in northern Illinois (fig. 4) to address flooding problems in this area. The runoff from this rainfall produced record flood discharges at 19 USGS streamflow-gaging stations (table 2), with near record discharges at several more stations. IDNROWR operated 6 continuousrecording stage gages and 60 crest-stage gages in the flood area. The crest-stage gages record only the peak stage (elevation) of the stream. The digital-time series (in 15-minute increments) of discharge and(or) stage for all USGS and IDNROWR gages are listed in appendix 1. Peak stage data for the IDNROWR crest-stage gages in the flood area are listed in table 3.

Using methods outlined in Bulletin 17B (Hydrology Subcommittee of Interagency Advisory Committee on Water Data, 1982), a Log Pearson Type III distribution was fit to the annual peak data set for each USGS continuous streamflow-gaging station to obtain the flood-frequency estimates. Where applicable, using the weighting scheme recommended in Curtis (1987, p. 4), the station frequency estimates were weighted with the regional flood-frequency estimates of Curtis (1987) to produce the floodfrequency estimates for each station. Eleven stations had peak discharges that were greater than the 100 -year flood discharge, which is defined as the discharge with a 1-percent chance of occurrence in any one year. The frequency estimate for each station, peak discharge, and stage are listed in table 2.

The discharge peaks for the streams and rivers in the flood area occurred anywhere from a few hours to a day after the rainfall, depending on the size of the stream. Discharge hydrographs for five selected streamflow-gaging stations in the flood area are shown in figure 5 .

Most of the available hydrologic data collected in the flood area are shown on plate 1. The data include rain-gage locations, point-rainfall observations and isohyets, USGS streamflow-gaging station locations, and flood-frequency information.

\section{SUMMARY}

Record flooding occurred on many streams in northern Illinois during July 18-20, 1996. This flooding was caused by record rainfall from several subsequent thunderstorms tracking along the same west to east stalled low-pressure front. A new State of Illinois 24-hour record rainfall of 16.91 in. was recorded at Aurora. The National Weather Service rain gages at Aurora and De Kalb had frequency estimates greater than the 100-year recurrence interval. Peaks of record were recorded at 19 U.S. Geological Survey streamflow-gaging stations. Peak discharges in excess 

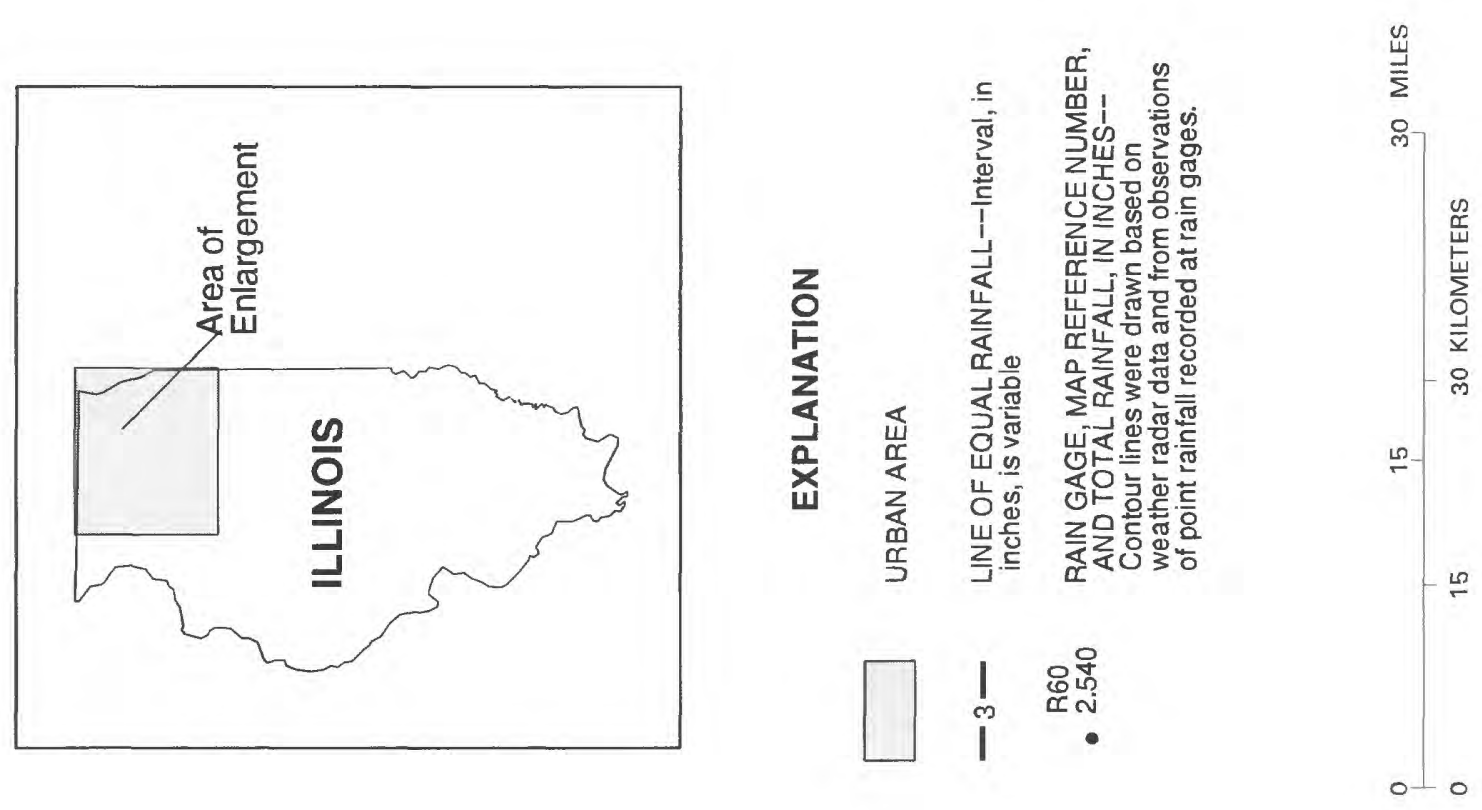

\section{Lake Michigan}

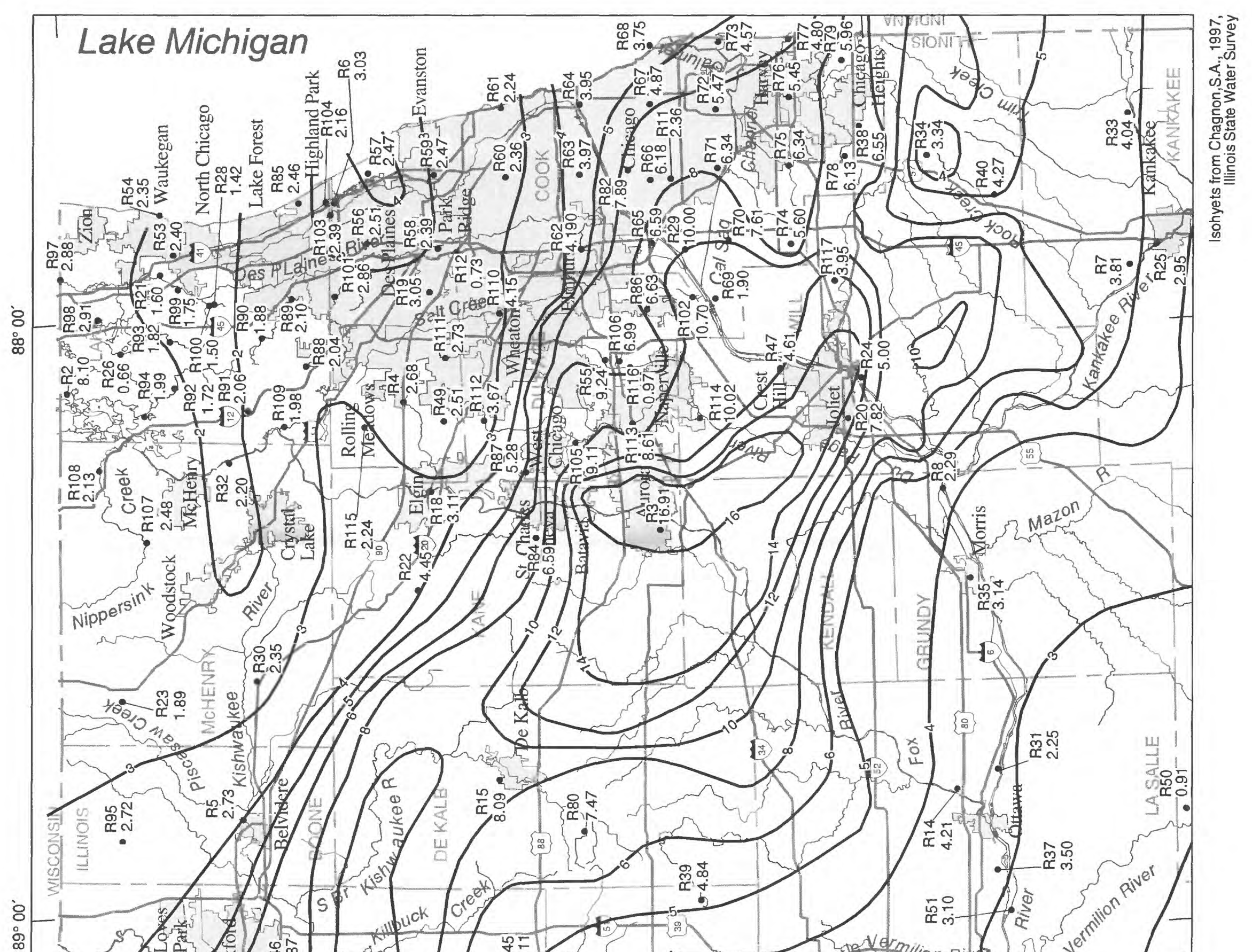

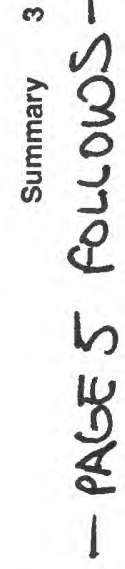

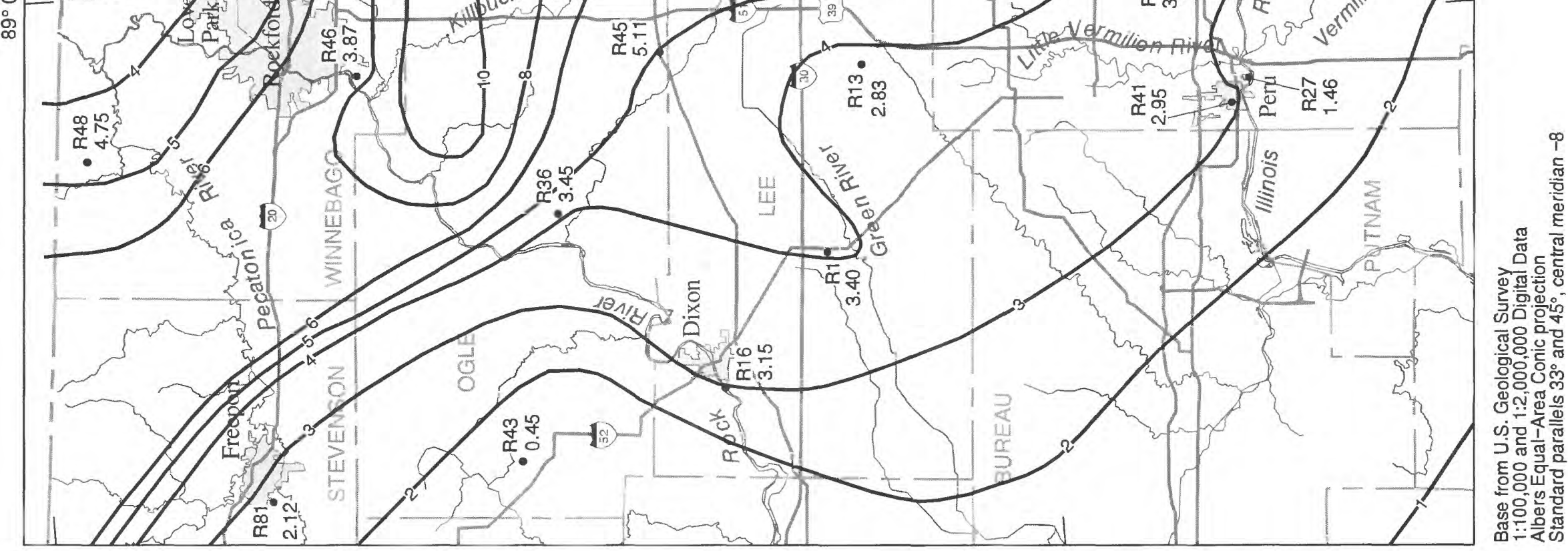




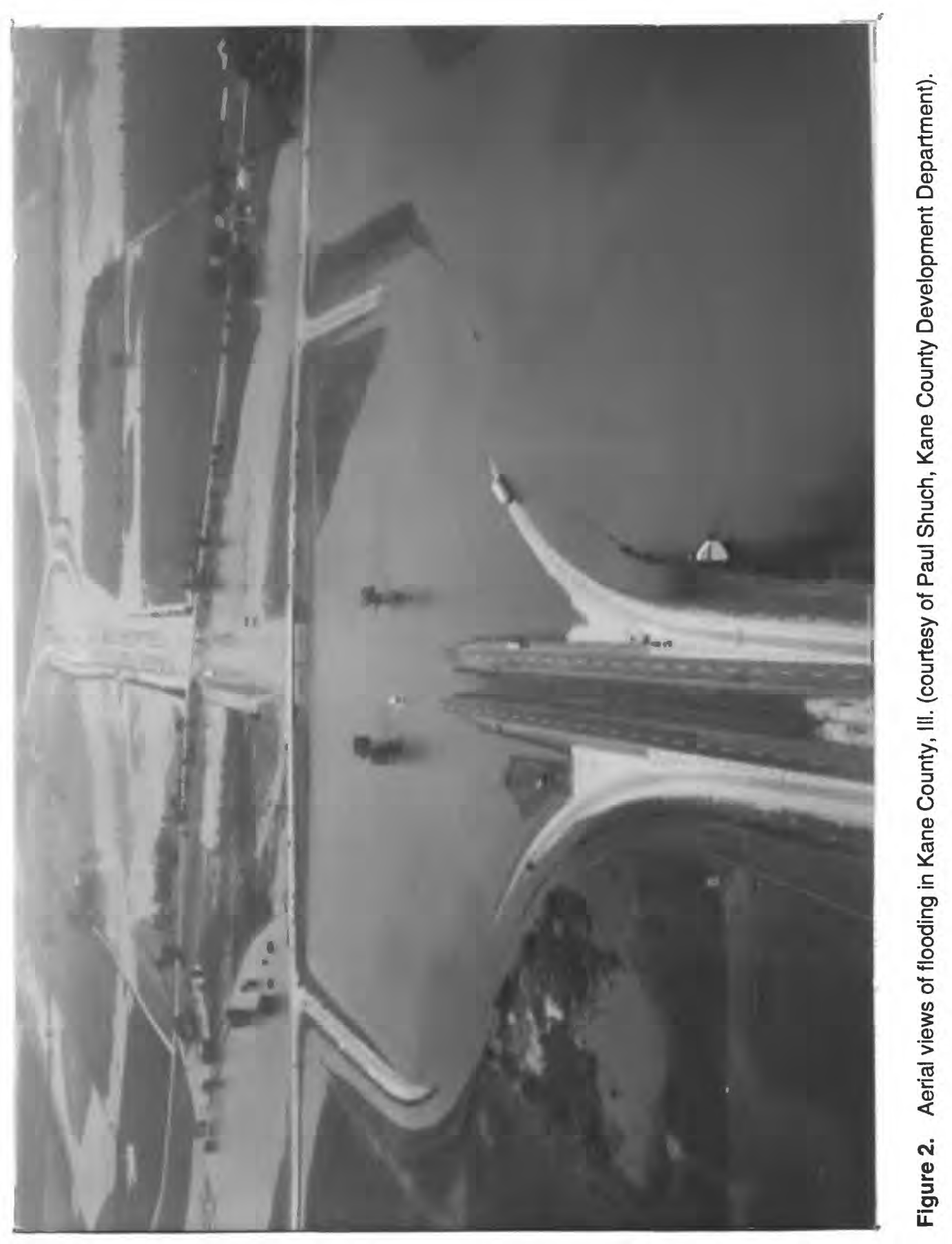




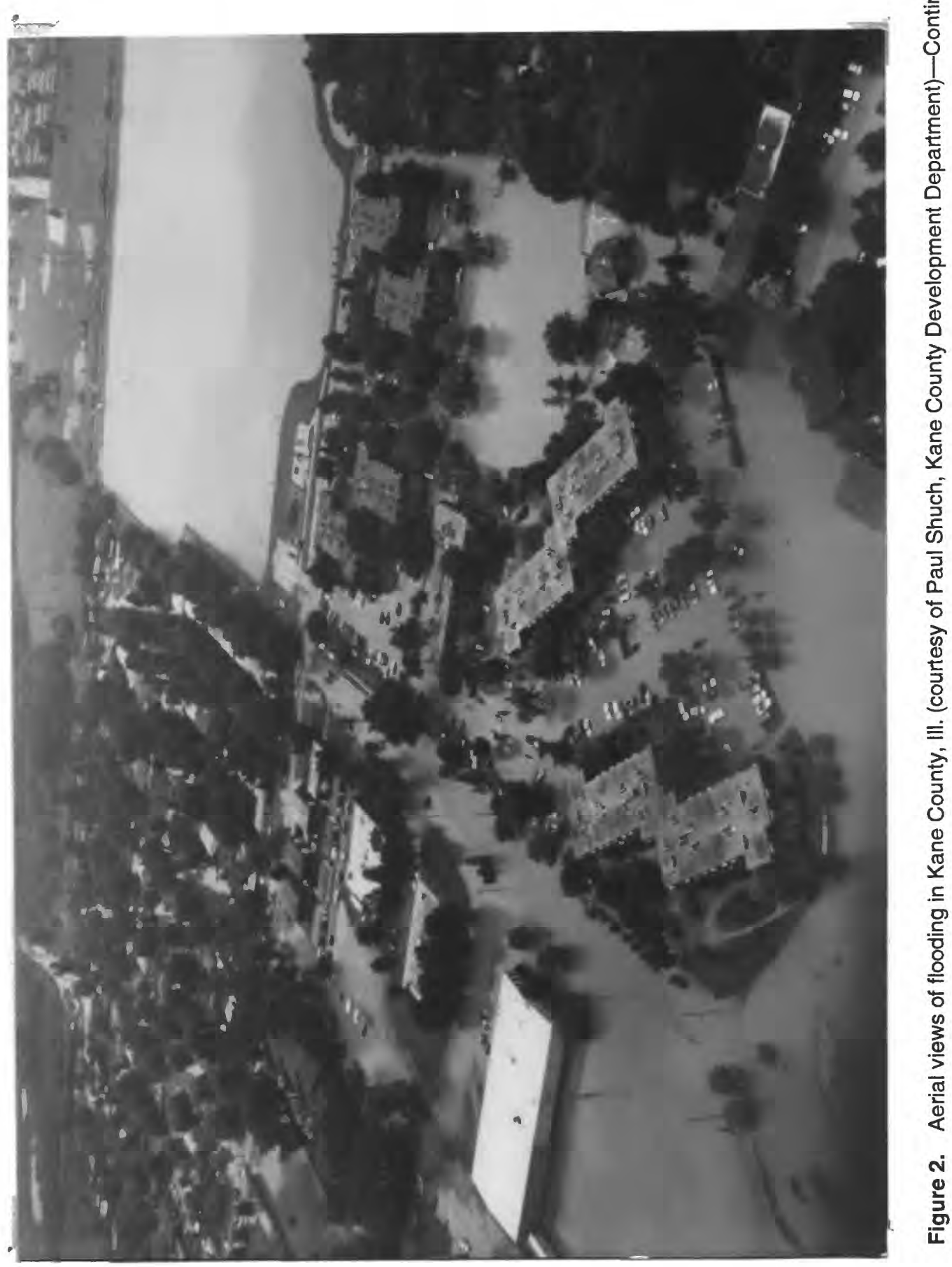




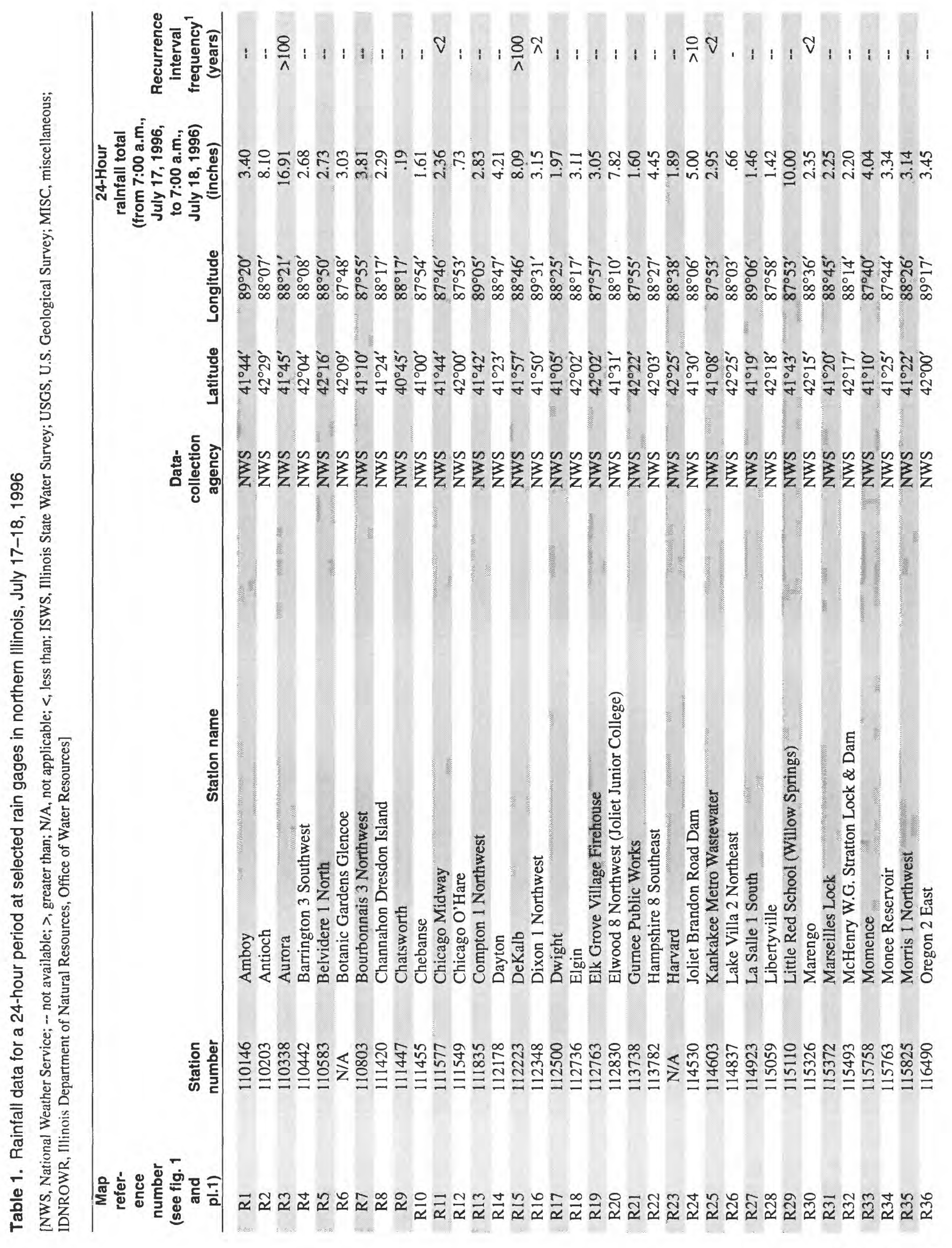




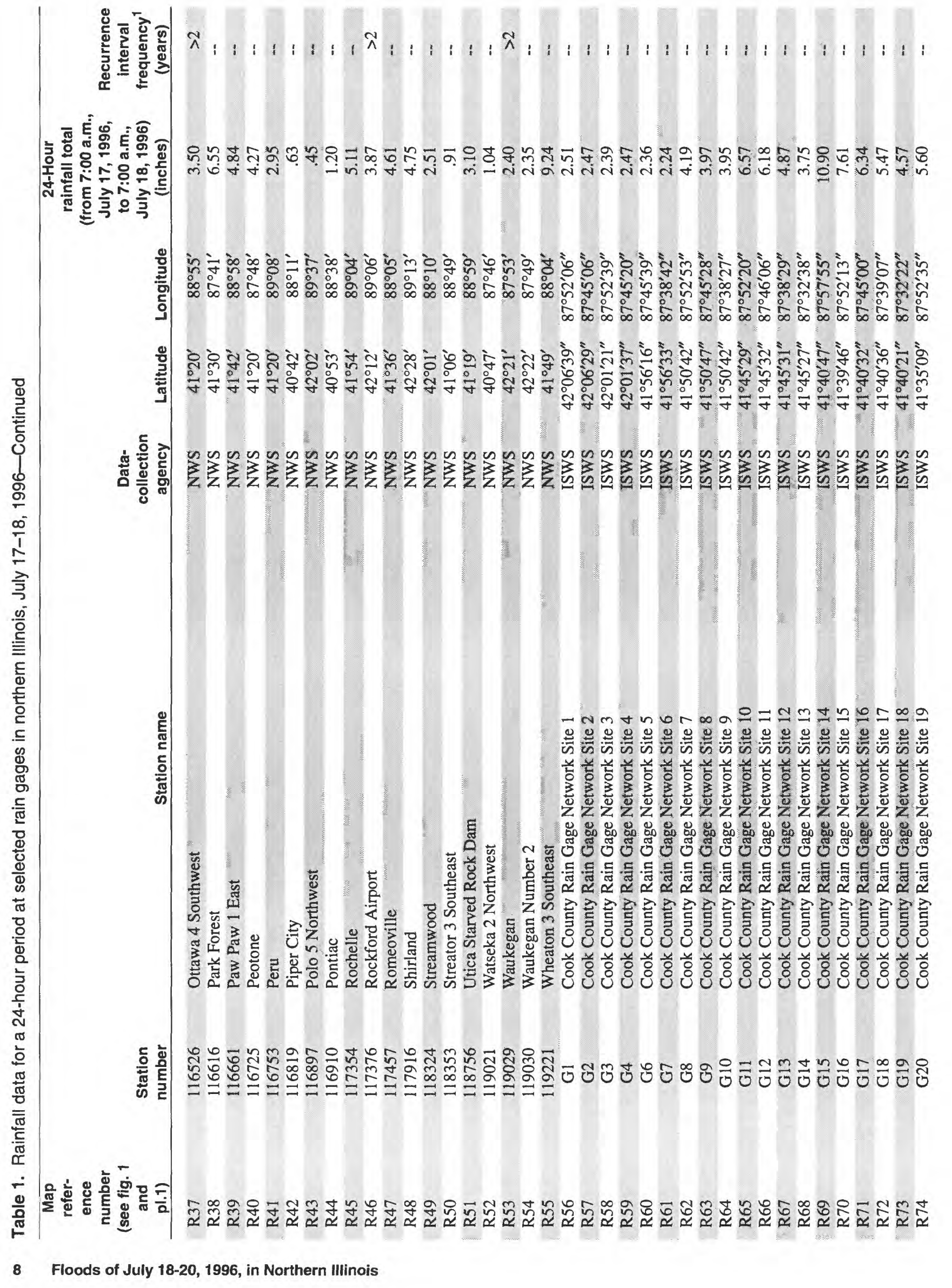




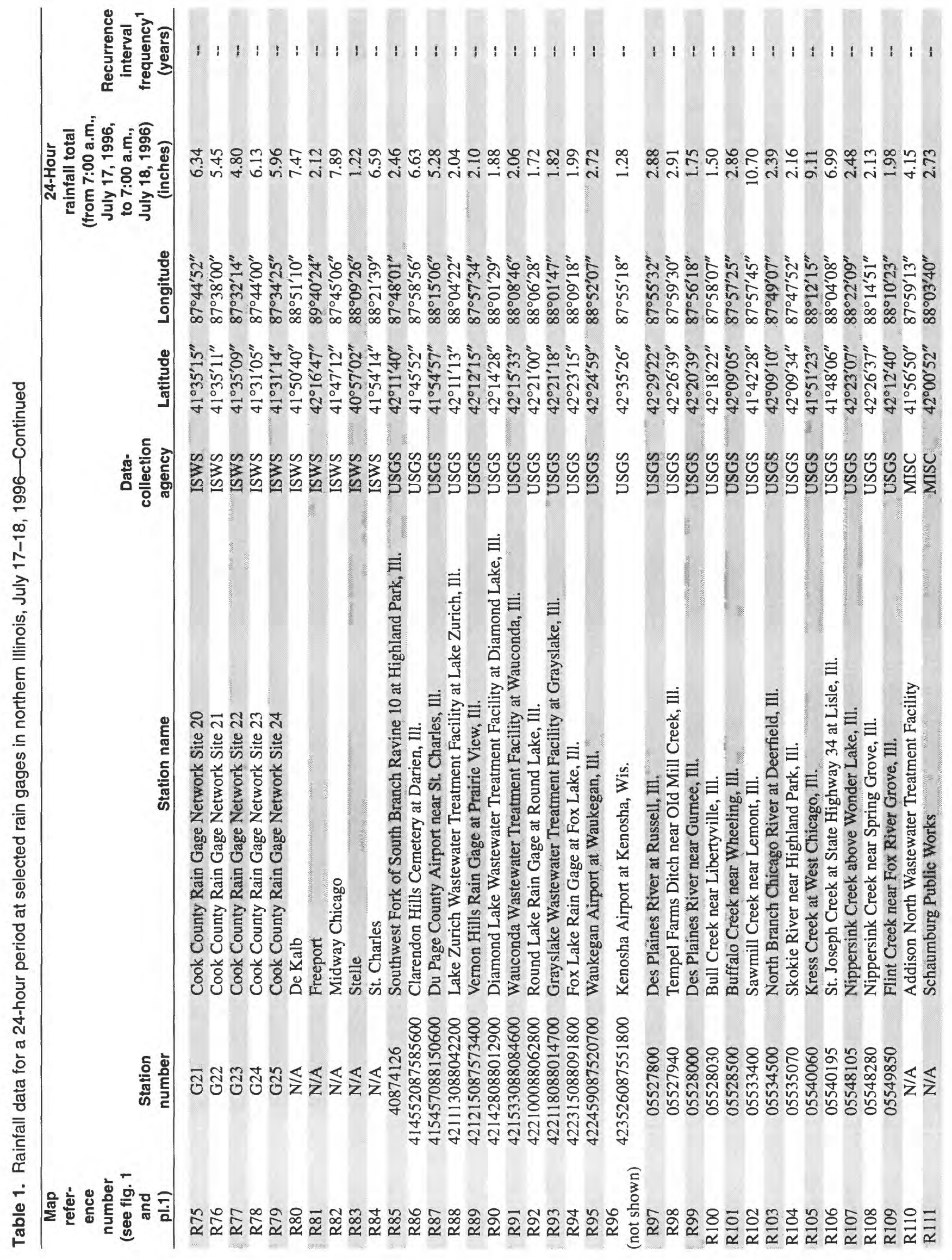




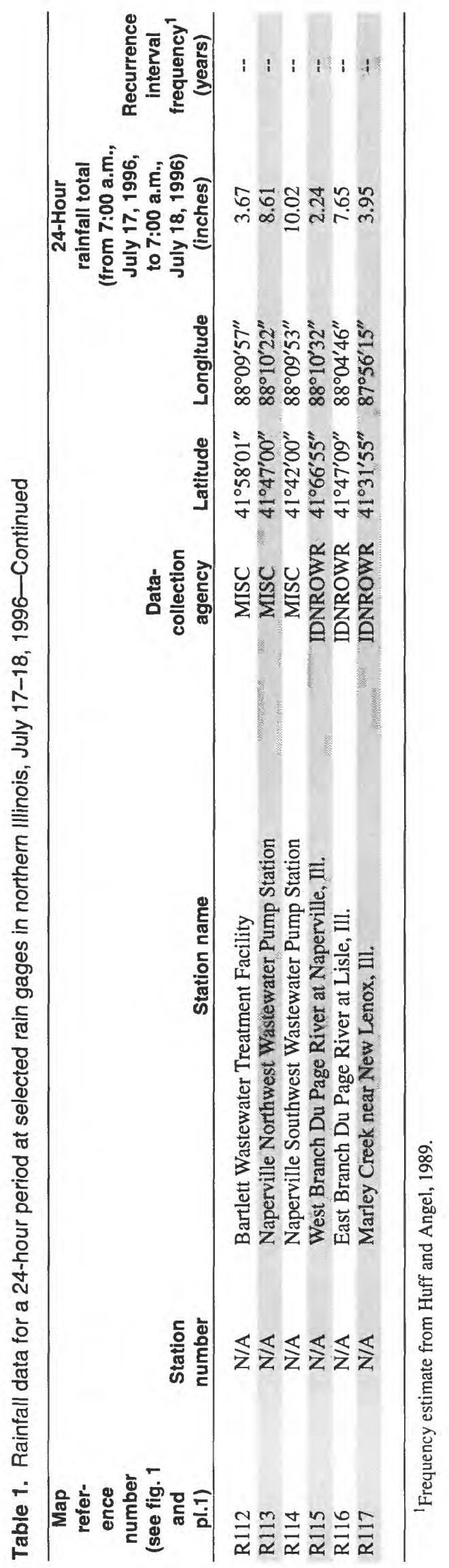

10 Floods of July 18-20, 1996, in Northern Illinois 


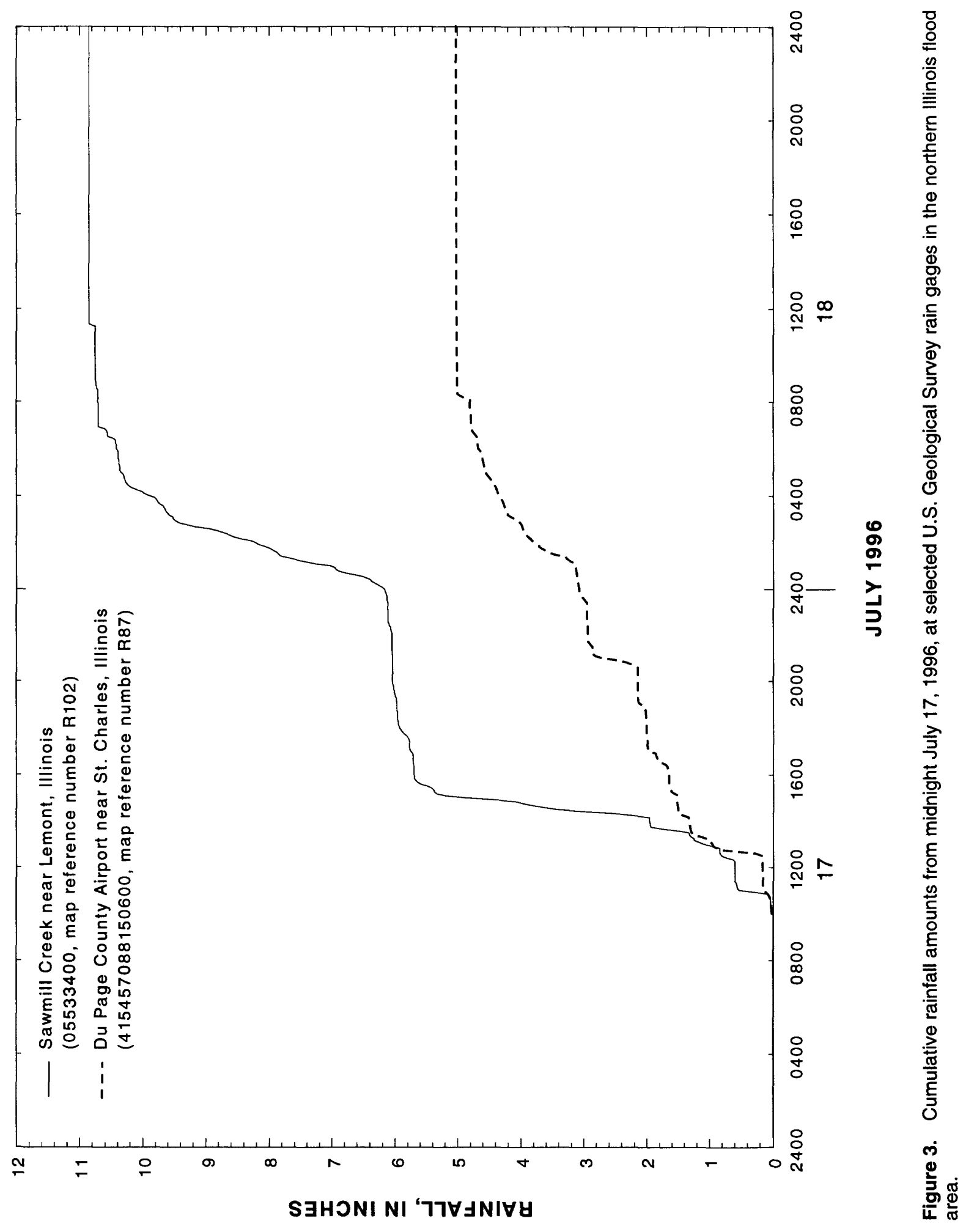



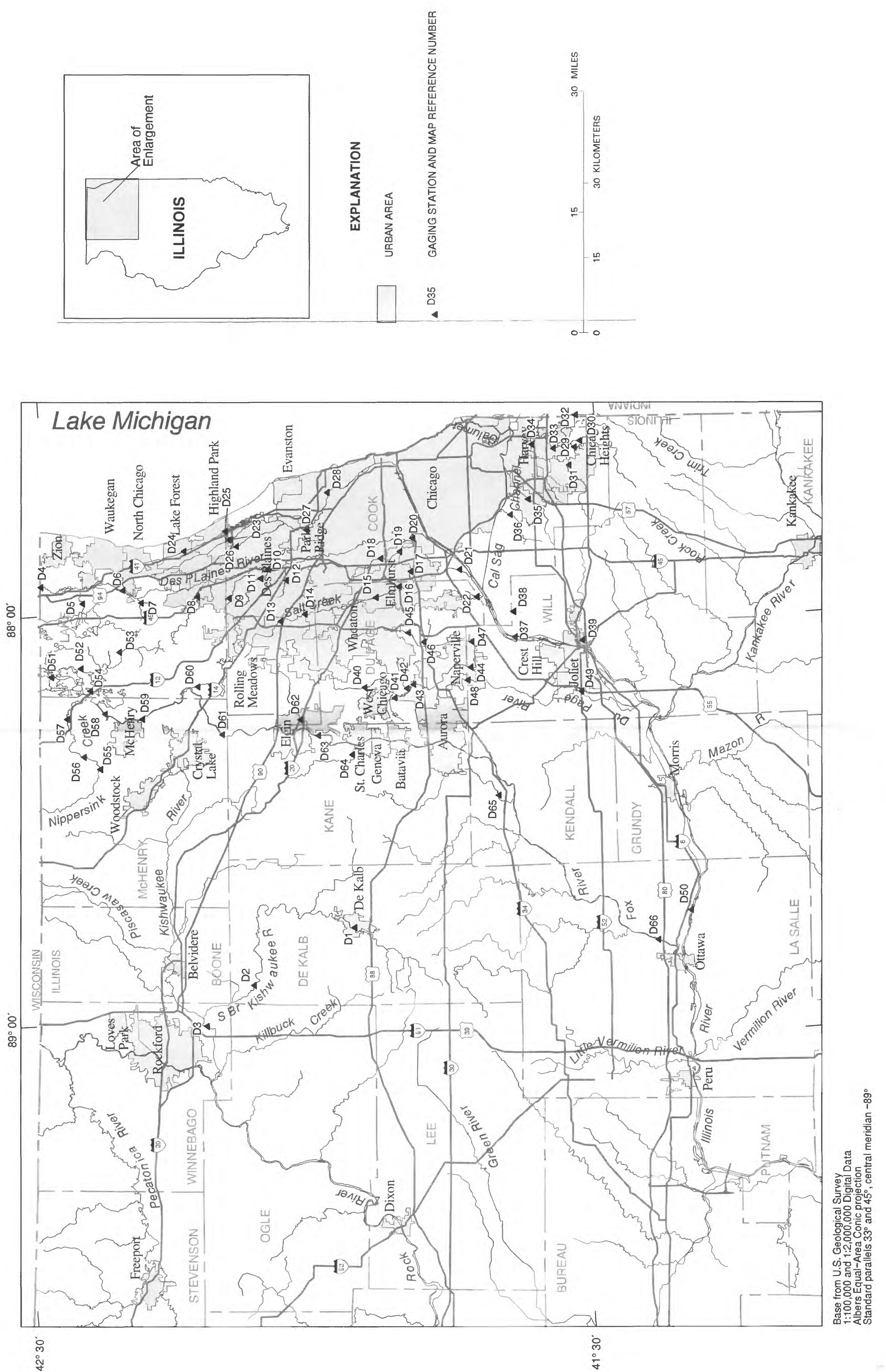

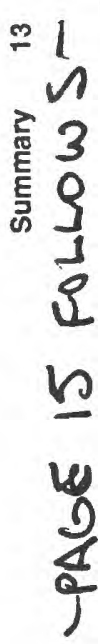




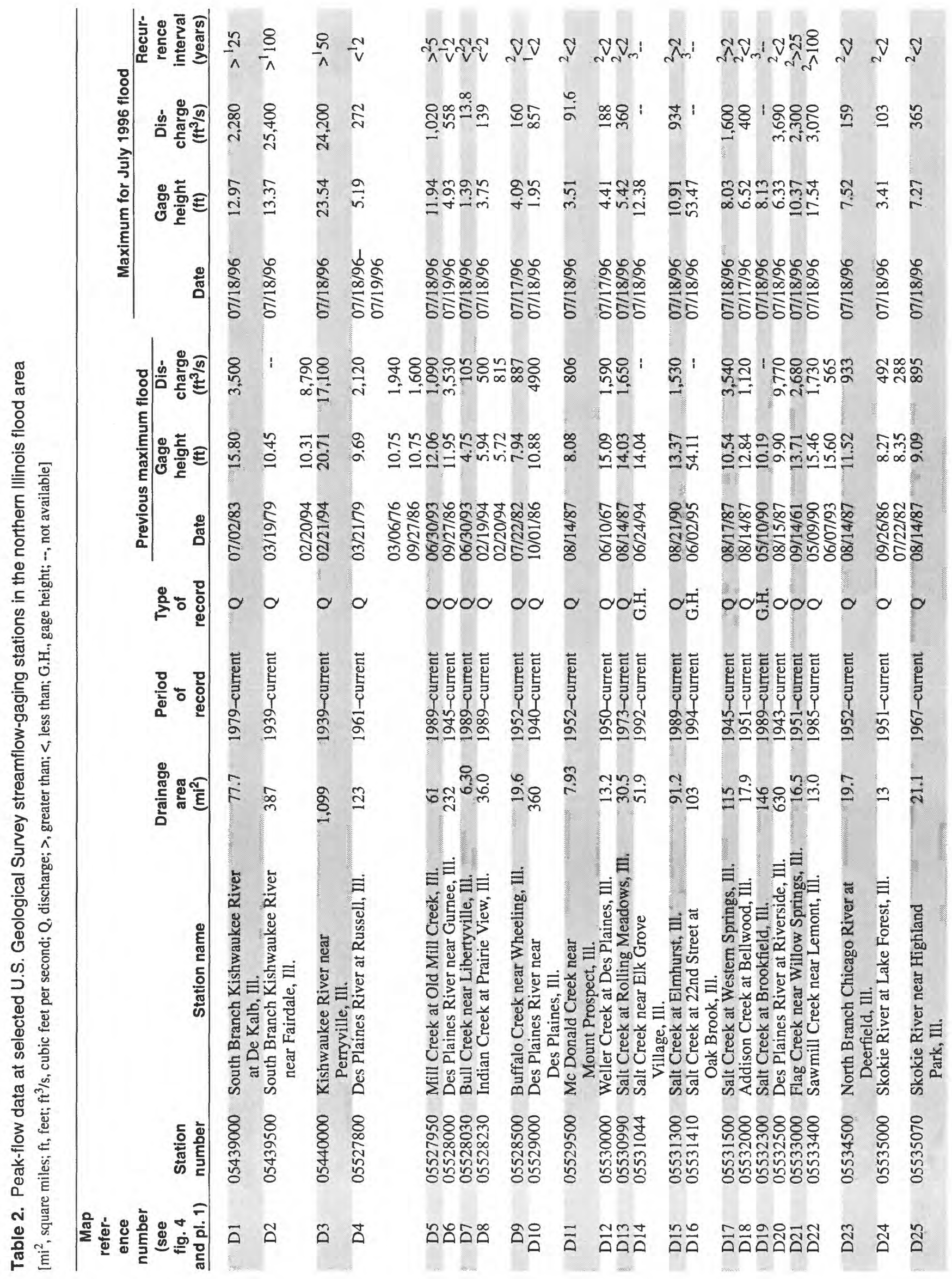




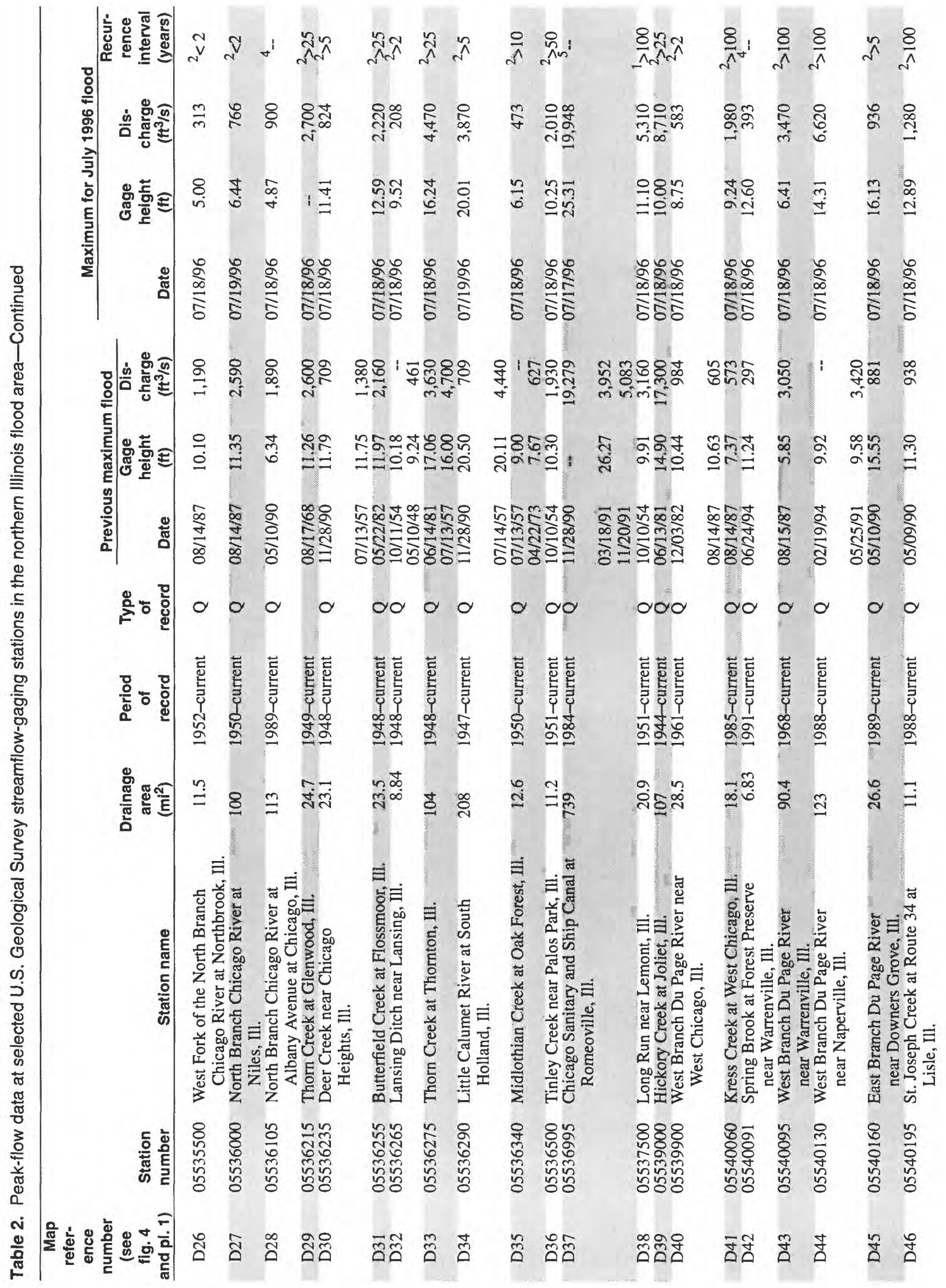




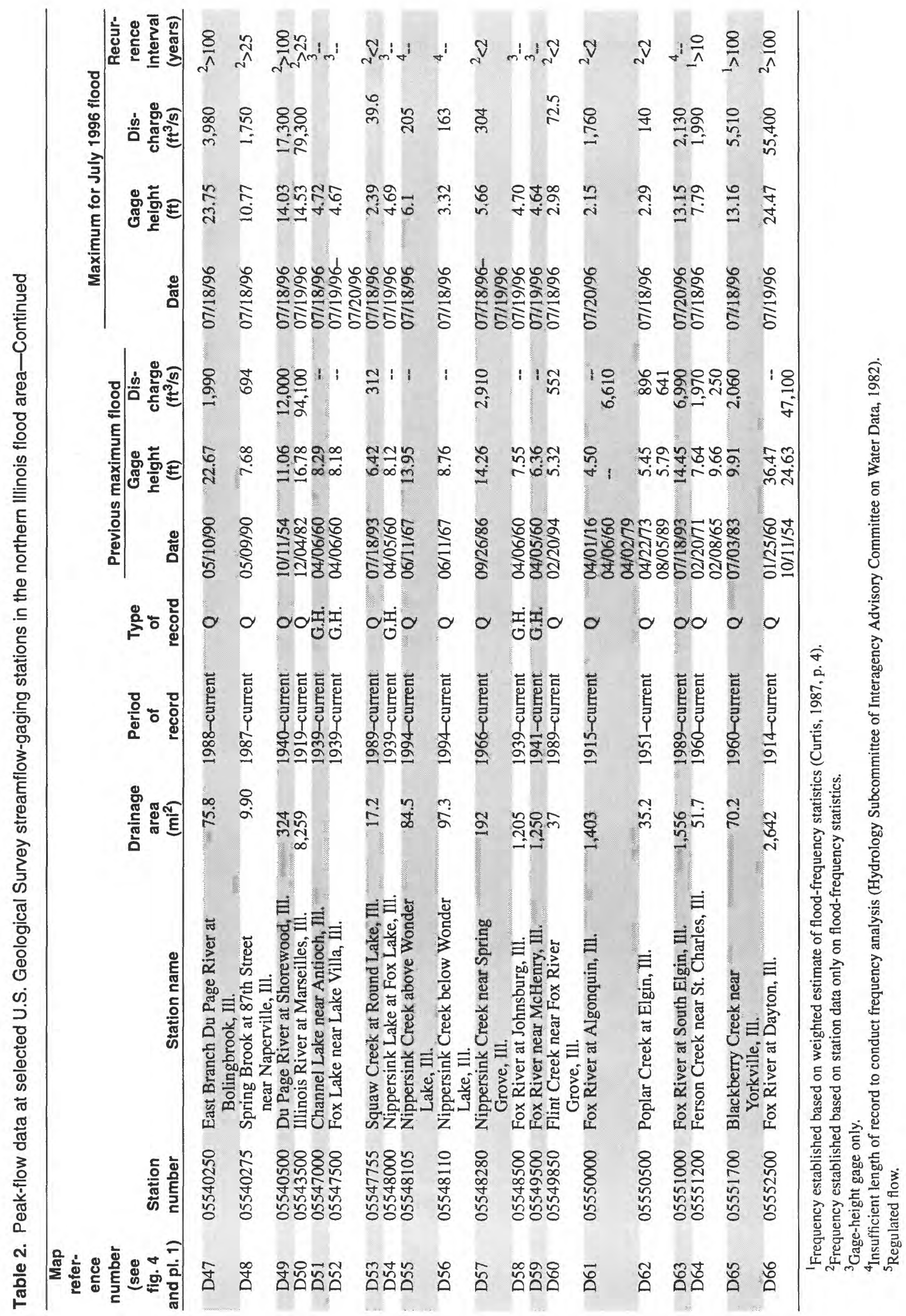




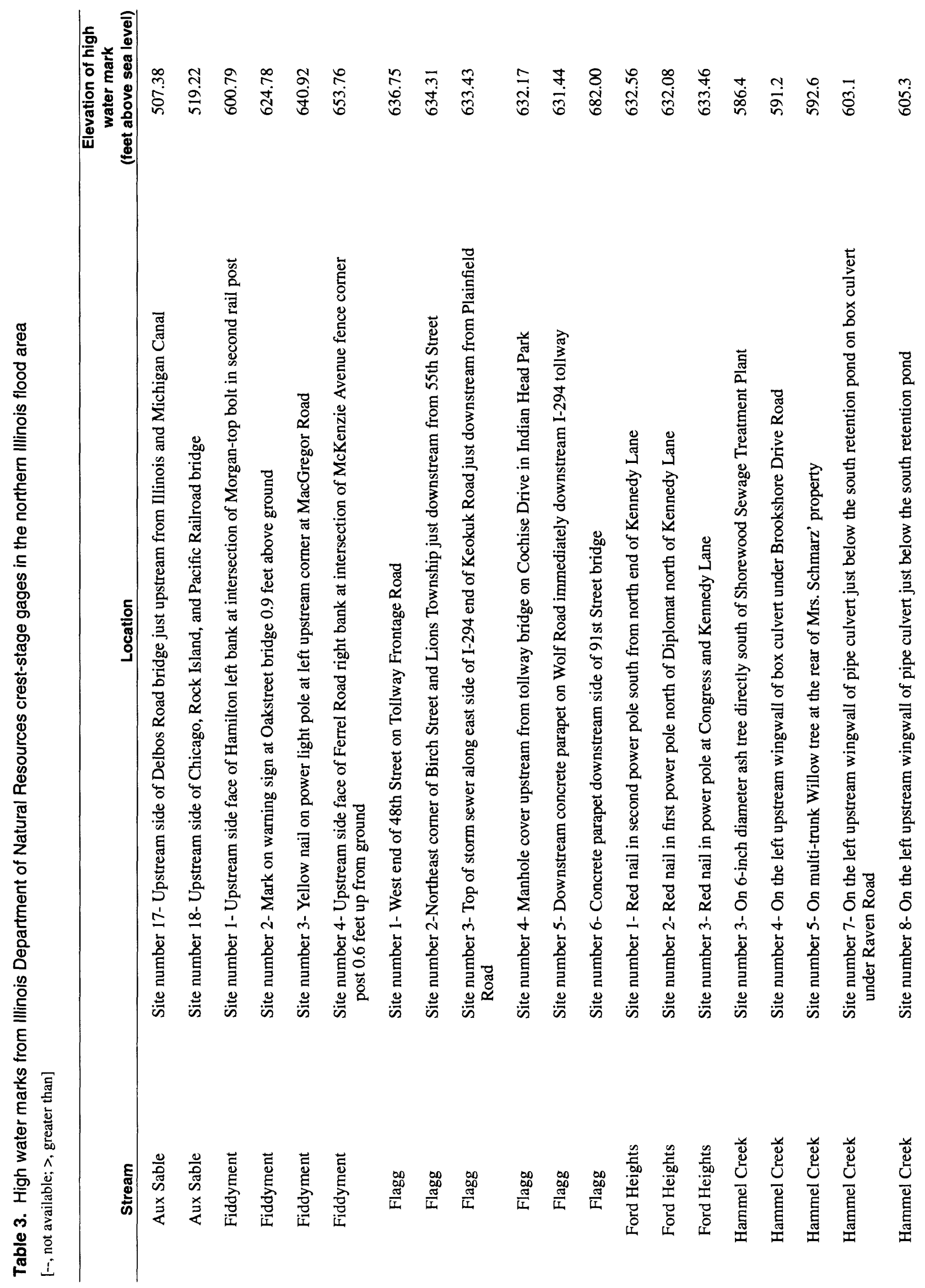




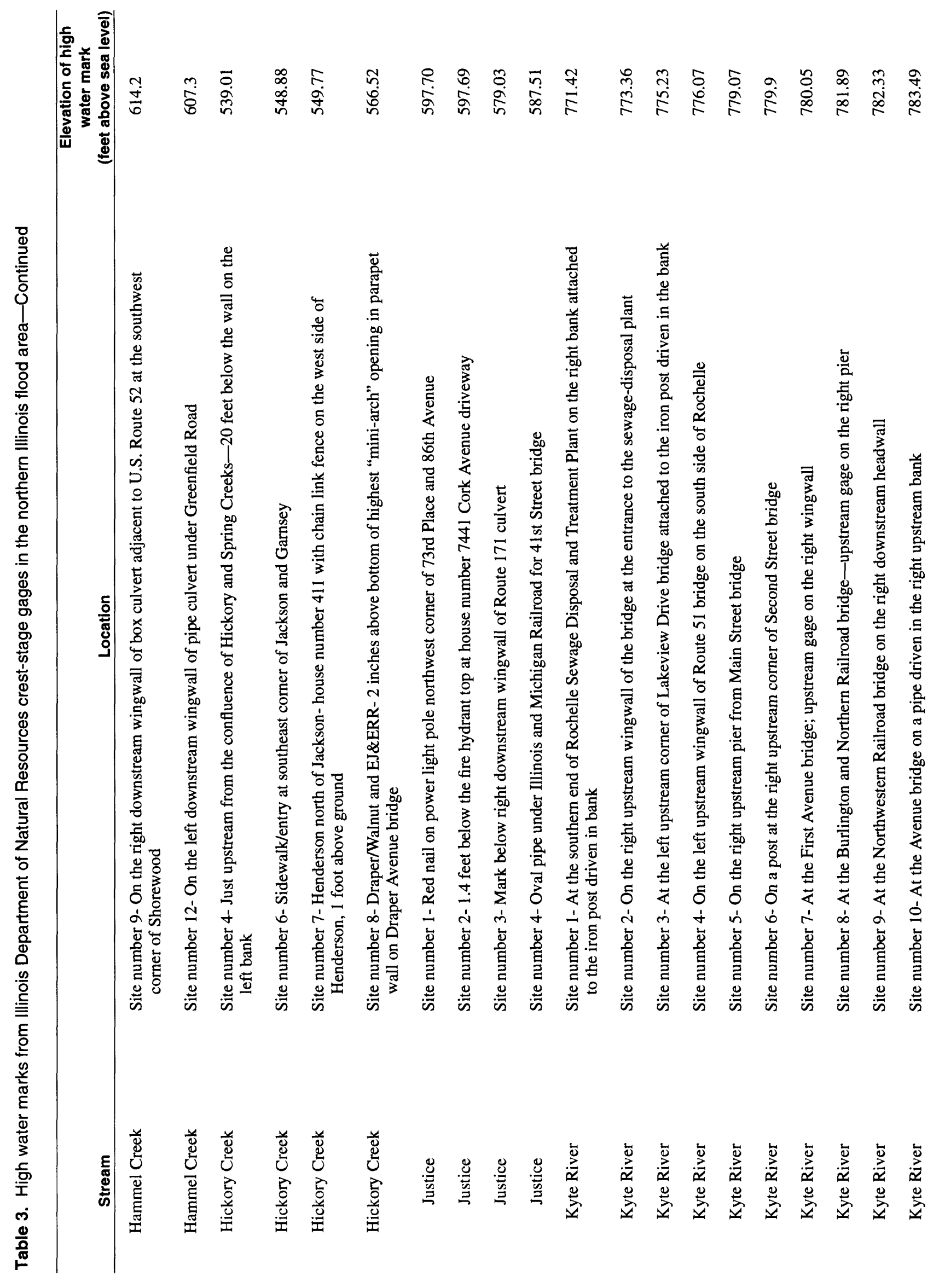




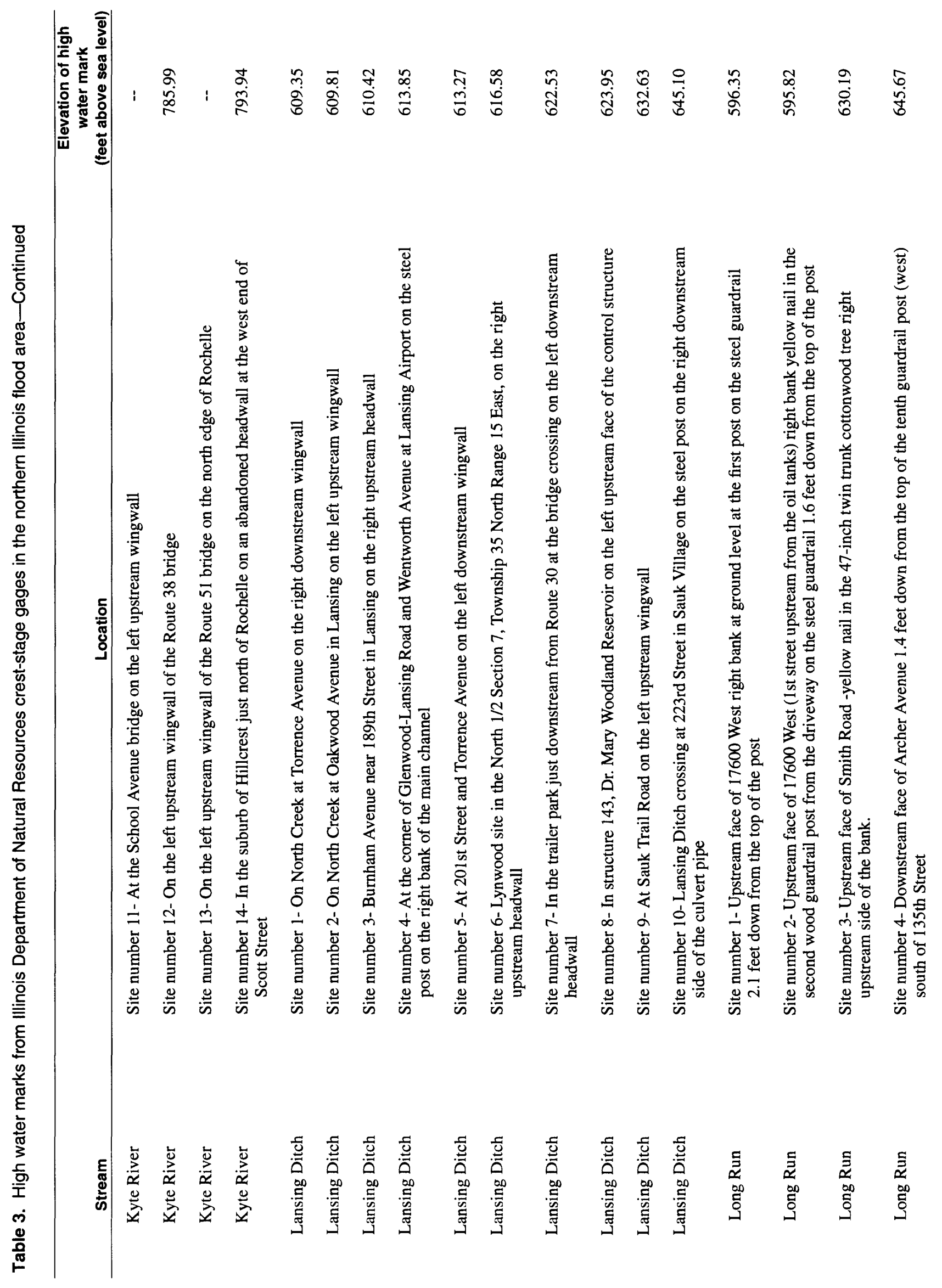




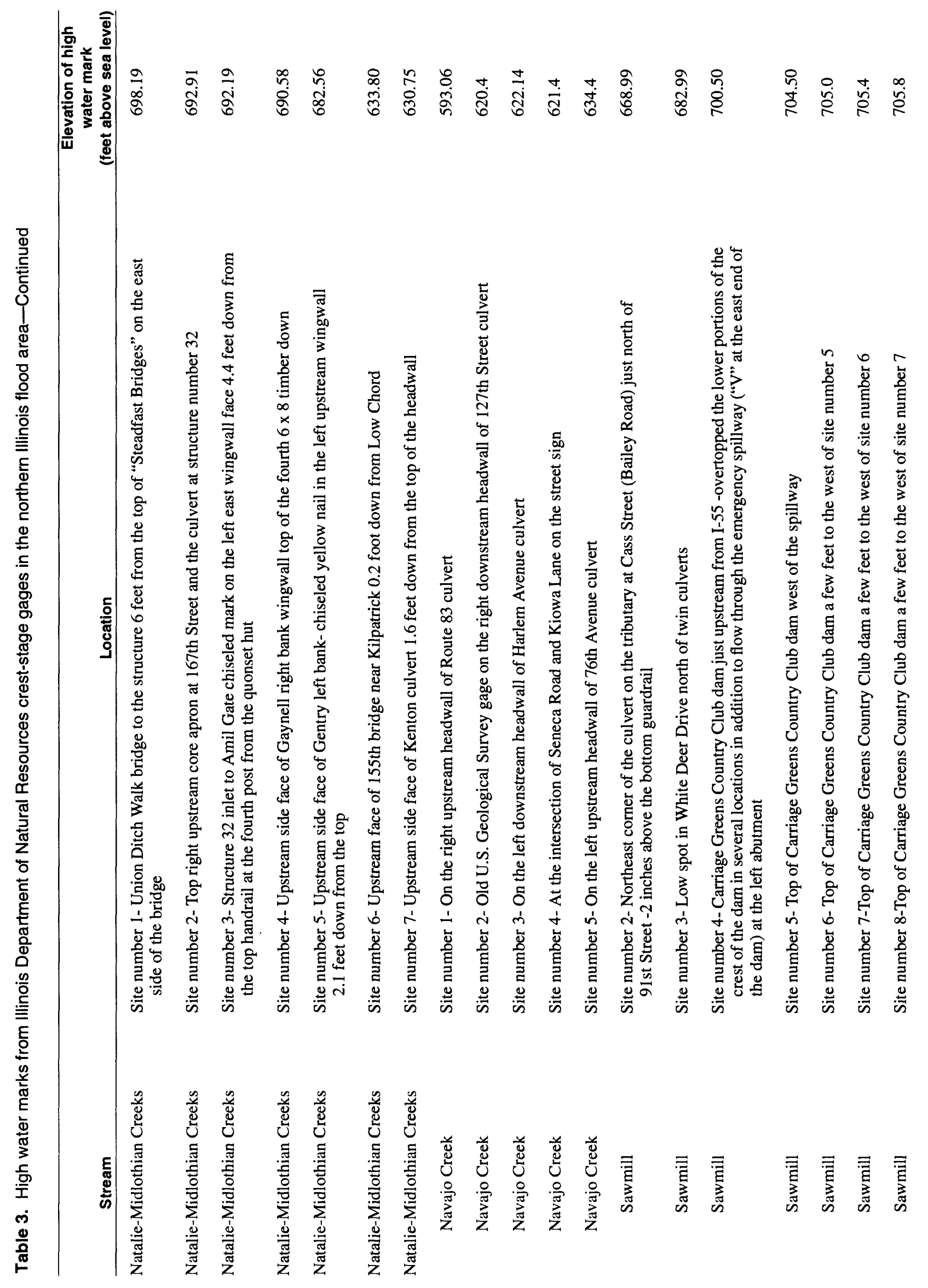




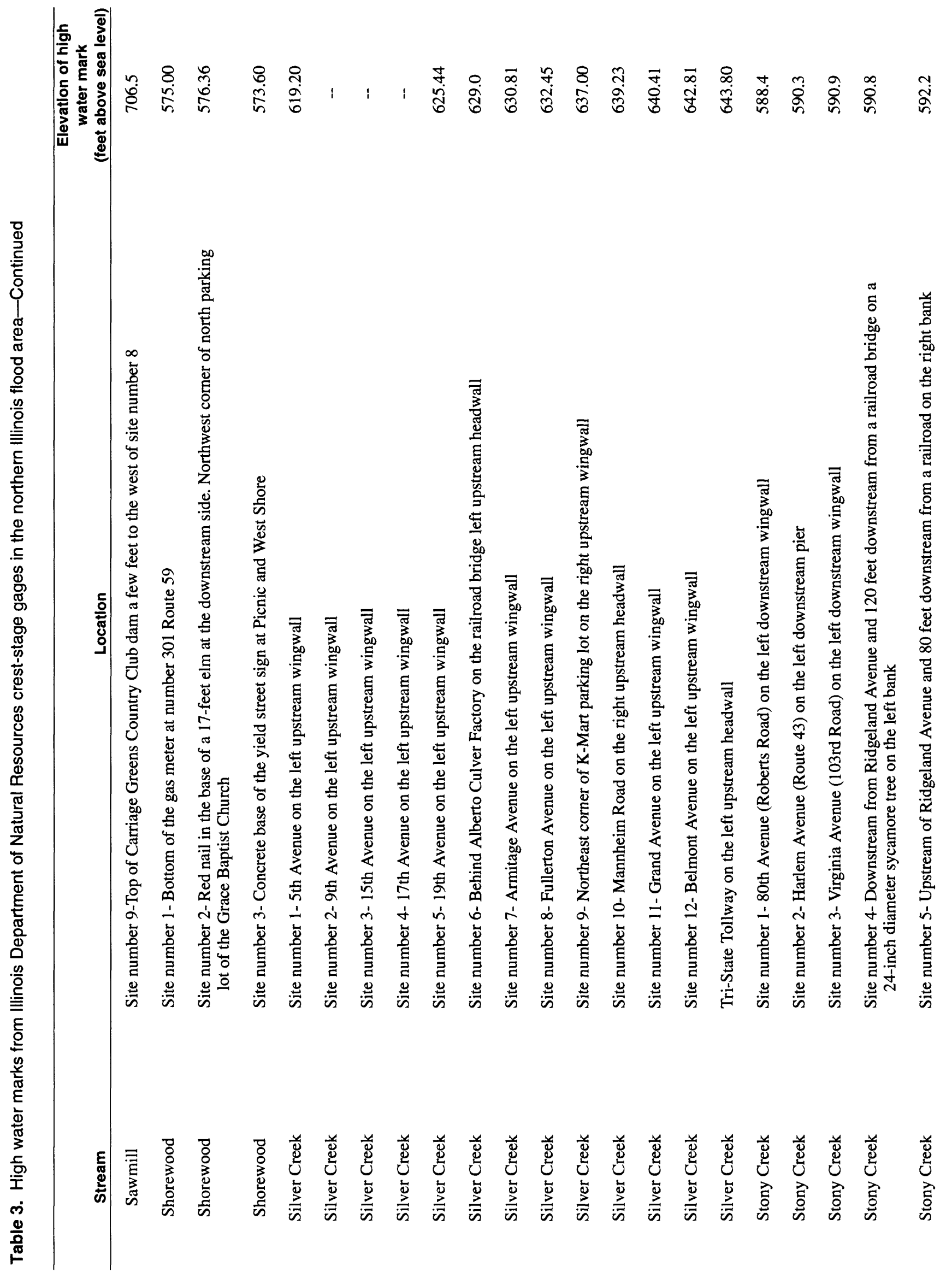

22 Floods of July 18-20, 1996, in Northern Illinois 


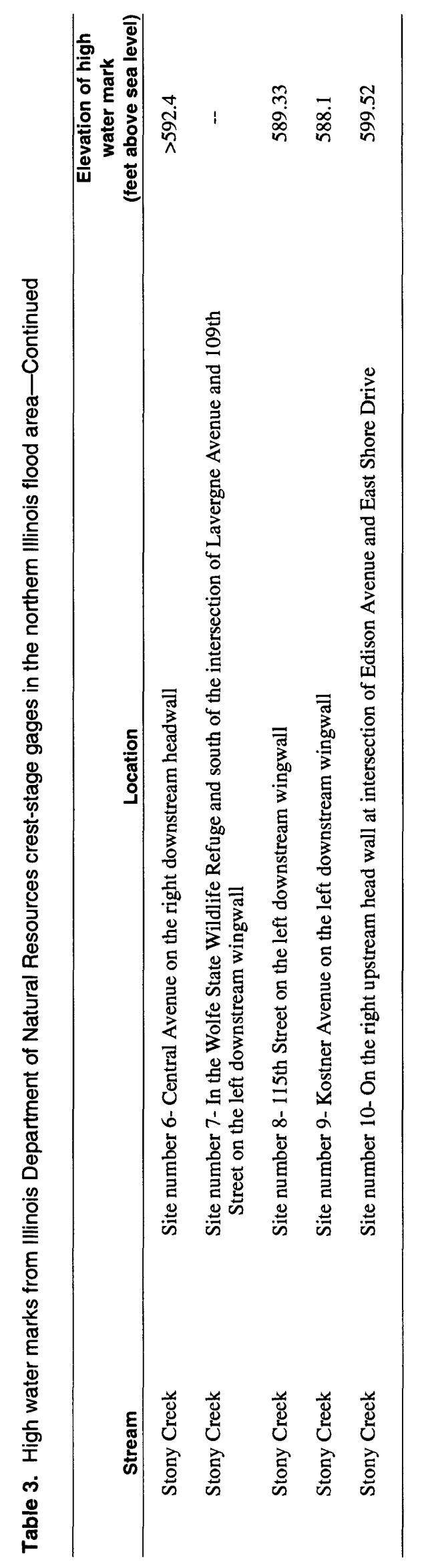




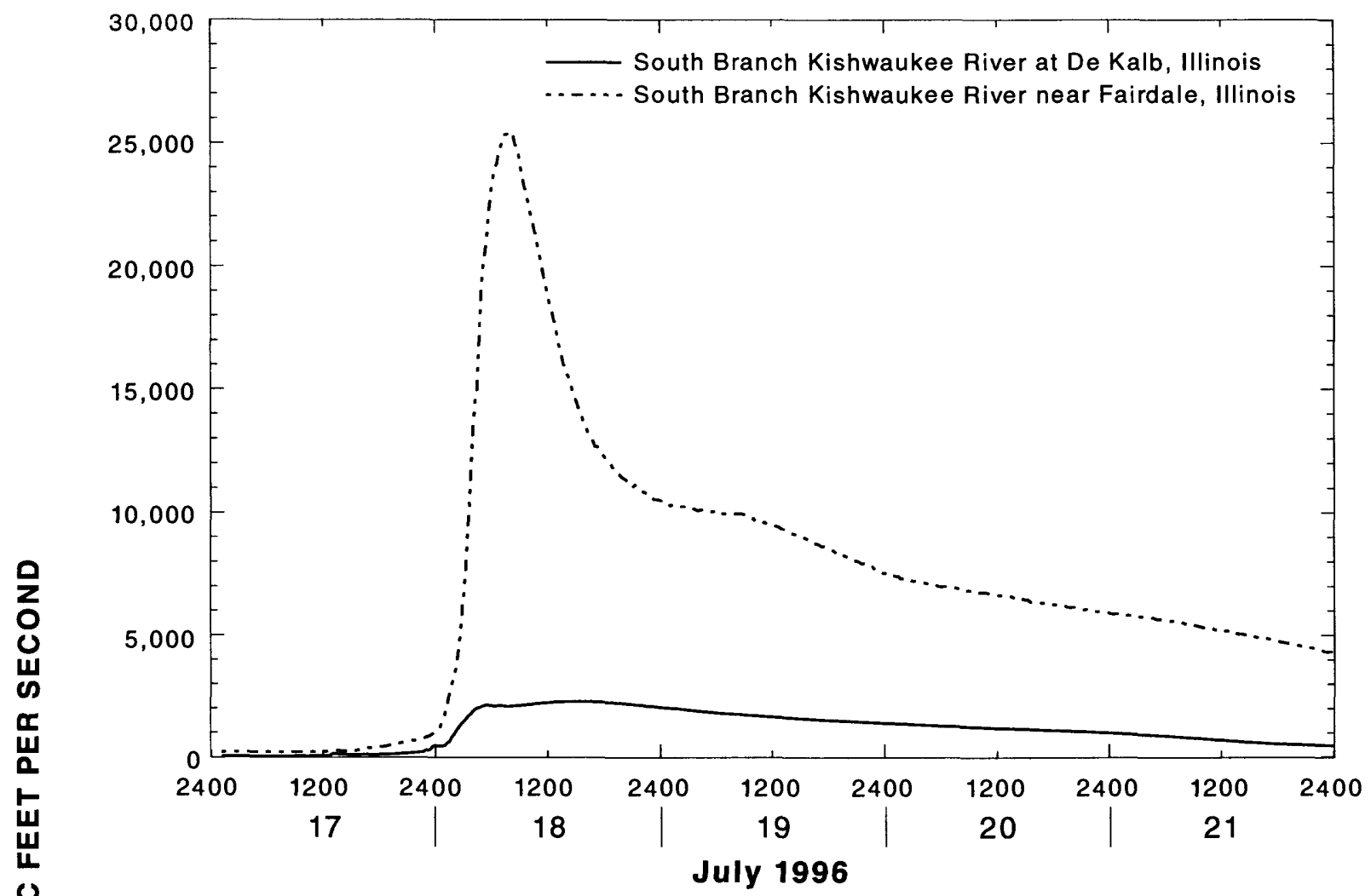

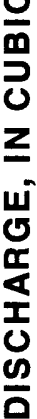

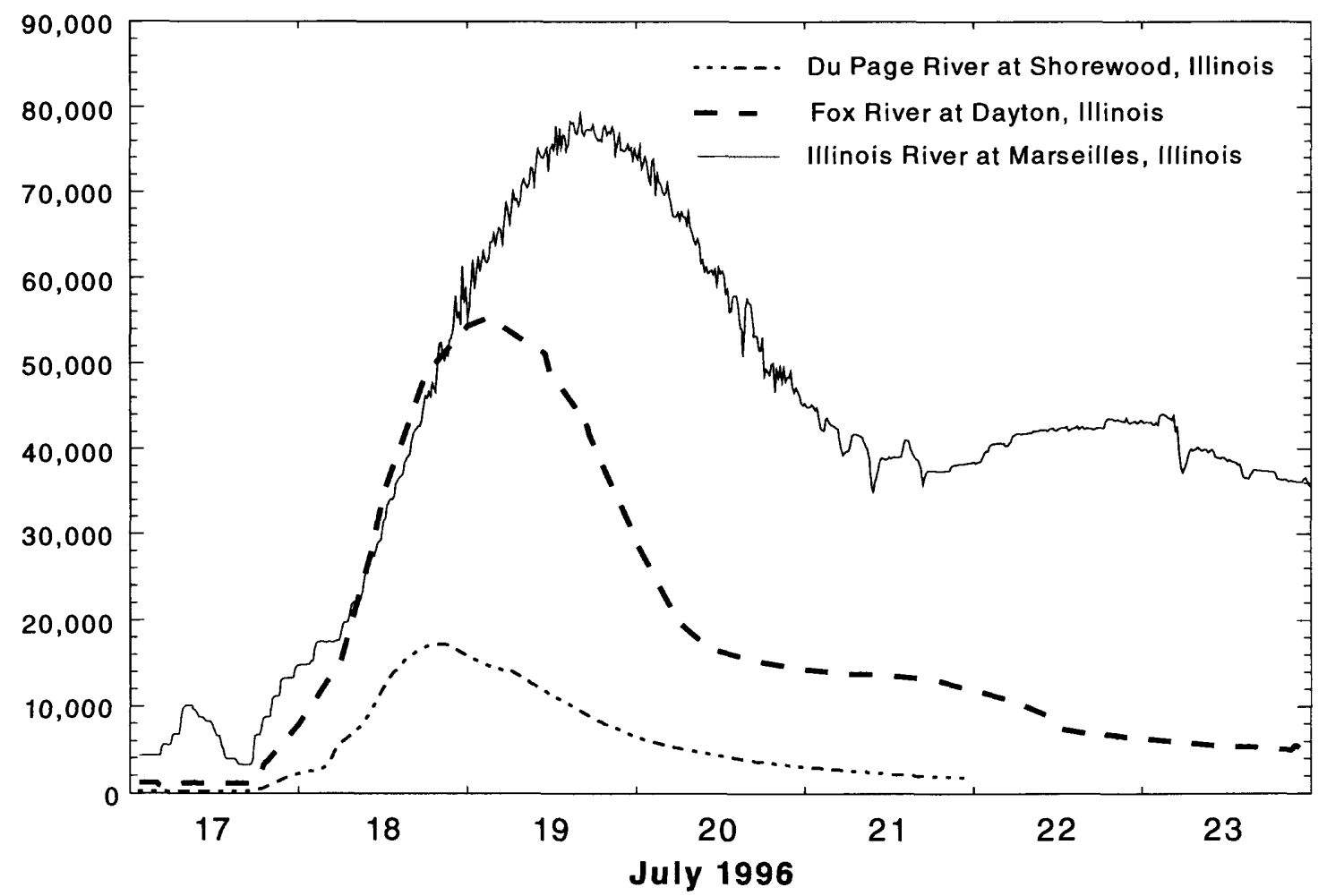

Figure 5. Flood discharge hydrographs for selected U.S. Geological Survey streamflow-gaging stations in the northern Illinois flood area. 
of the estimated 100-year flood frequency were estimated at 11 continuous streamflow-gaging stations.

\section{REFERENCES}

Chagnon S.A., ed, 1997, The record rainstorm on July 17-18, 1996 in northern Illinois: Illinois State Water Survey, Miscellaneous Publication, MCC Research Report 97-02, $160 \mathrm{p}$.

Chicago Tribune, 1996, After the deluge, work and worries, July 21 , Chicago Tribune, 150th year, no. 203, section 1, p. 1.

1996, Federal disaster aid to help flood victims in 11 counties, July 26 , Chicago Tribune, 150 th year, no. 208 , section 2 , p. 1.
Curtis, G.W., 1987, Technique for estimating flood-peak discharges and frequencies on rural streams in Illinois: U.S. Geological Survey Water-Resources Investigations Report 87-4207, 79 p.

Huff, F.A., and Angel, J.R., 1989, Frequency distributions and hydroclimatic characteristics of heavy rainstorms in Illinois: Illinois State Water Survey Bulletin 70, $177 \mathrm{p}$.

Hydrology Subcommittee of Interagency Advisory Committee on Water Data, 1982, Bulletin 17B, Guidelines for determining flood flow frequency: U.S. Geological Survey, Office of Water Data Coordination, Reston, Virginia, 183 p. 
APPENDIX

PAGE 29 FOLLOWS - 


\section{Appendix 1.}

This appendix consists of the time series discharge, stage, and rainfall digital data for the July 1996 flood in northern Illinois. The data were contained on a 3.5 in.

floppy disk. An index to the data is listed in the file SUMM.TXT. All the data were compressed and will need to be decompressed before the files can be read. 